\title{
Erratum to: Virial Approximation of the TEOS-10 Equation for the Fugacity of Water in Humid Air
}

\author{
Rainer Feistel • Jeremy W. Lovell-Smith • \\ Olaf Hellmuth
}

\section{Erratum to: Int J Thermophys DOI 10.1007/s10765-014-1784-0}

After online publication of the article, regarding an unresolved question in Sect. 4, A.H. Harvey (priv. comm.) kindly informed the authors that the virial coefficients of water compiled by Nelson and Sauer, Ref. [10] in the article, were fitted to values he had computed from IAPWS-95, Ref. [7] in the article, and provided to those authors.

The online version of the original article can be found under doi:10.1007/s10765-014-1784-0.

R. Feistel $(\varangle)$

Leibniz Institute for Baltic Sea Research (IOW), 18119 Warnemünde, Germany

e-mail: rainer.feistel@io-warnemuende.de

J. W. Lovell-Smith

Measurement Standards Laboratory (MSL), PO Box 31-310, Lower Hutt, New Zealand

O. Hellmuth

Leibniz Institute for Tropospheric Research (TROPOS), 04318 Leipzig, Germany 